\title{
Fangers opplevelser av skam og stolthet etter soning
}

\author{
Af Gitte Svennevig, ${ }^{1}$ Magne Haukland ${ }^{2}$ og Dag Willy Tallaksen ${ }^{3}$
}

\begin{abstract}
The aim of this study is to examine former prisoners' experiences of shame in life after imprisonment, and how processes of change from shame to pride take place.

Qualitative in-depth interviews are conducted with seven former prisoners affiliated with the self-help organization WayBack. The empirical material is processed using content analyses. A hermeneutic phenomenological framework inspired the study.

The study shows that the movement from shame to pride is closely related to empowerment and to a change from marginalization to integration.

The analysis reveals that shame is activated by society's limited acknowledgement of ex-prisoners. Social arenas of equals can be experienced as essential to create new identities and a sense of empowerment. Acknowledging that change requires acceptance of help from others - as well as provision of help to others, appears to be an important facilitator of change from shame to pride.

The individual's opportunity to put words into feelings is central. Likewise, the achievement of coherence in the world (SOC) is of crucial importance. The importance of being recognized and achieving social value are also key findings of the research.
\end{abstract}

Løslatte fanger kan oppleve at møtet med samfunnet utenfor murene er en ny og vanskeligere form for straff enn fengselssoning. Skylden kan være gjort opp for, men ikke nødvendigvis skammen forteller flere av dem. Til tross for stigma og omfattende utfordringer, er noen gjengangere i norske fengsler etter hvert i stand til å vende skam til stolthet (Svennevig 2012). Denne studien søker å belyse hvordan slike transformasjoner kan finne sted, ut fra tilnærmingen «Hvordan opplever tidligere fanger skam og stolthet, og hvordan kan endringsprosesser ta form?»

Gjennom flere tiår har det vært høyt tilbakefall til kriminelle handlinger. Fangene i denne studien er alle dømt flere ganger til fengselsstraff for tyveri og nar-

* Title in English: Prisoners' self-perceived shame and pride after imprisonment. 
kotikaforbrytelser. Dette er betegnende for gruppen med høyest tilbakefall, rundt $80 \%$ (Graunbøl m.fl. 2010).

I fengslene finner vi mennesker utsatt for omsorgssvikt og andre utfordringer i oppveksten, de med manglende utdanning og tilknytning til arbeidsmarkedet, de fattigste, og de med dårligst helse og økt risiko for rusproblemer (Revold 2015, Friestad \& Hansen 2004). Undersøkelser av rusmisbrukere bekrefter tendensene: tidlige belastninger henger sammen med psykiske vansker og rusproblemer i voksen alder (Larsson, Lauritzen \& Ravndal 2012). Maktesløshet eller generelt manglende kontroll, kan medføre risiko for sykdom på mange områder (Getz, Kirkengen \& Ulvestad 2011).

\section{Metode, forskningsspørsmål og utvalg}

Til undersøkelse av eks-fangenes forståelser ble det anvendt en kvalitativ metode i form av dybdeintervjuer. Studien har en hermeneutisk-fenomenologisk tilnærming, der hensikten er å fremme fenomenene slik de de fremstår for deltakerne $\mathrm{i}$ deres livsverden, herunder å vise frem levde erfaringer og mening (Malterud 2003; Brinkmann \& Kvale 2012).

Forskningsspørsmål som ligger til grunn for studiens halv-strukturerte intervjuguide er:

- Hvordan opplever og erfarer tidligere fanger skam og stolthet?

- Hva kan fremme og hemme tidligere fangers opplevelse av skam, og av stolthet?

Det ble foretatt et strategisk utvalg sett $\mathrm{i}$ lys av hvem som hadde et engasjement å meddele og at de ikke var i en spesielt sårbar fase. Mangfold i utvalget var også ønsket. Det ble intervjuet sju personer, herav to kvinner. Tiden som hadde gått fra deltakernes siste løslatelse varierte fra tre måneder til syv år, de hadde sonet fra to til tretten fengselsdommer, og var i alderen 25 til 52 år. To var «faddere» og fem var medlemmer i WayBack. I forkant ble det informert om mulighetene for å trekke seg underveis. Det ble vurdert at «metning» var oppnådd etter syv intervjuer.

Materialet ble analysert ved kvalitativ innholdsanalyse (Malterud 2013; Brinkmann \& Kvale 2012). Først ble det søkt flest mulig variasjoner av tema for å sikre at sentrale funn ikke skulle forbigås blant annet som et resultat av forskers forforståelse. Meningsfulle enheter som besvarer forskningsspørsmålene ble identifisert, og disse ble heretter kondensert til 139 tema. Temaene ble abstrahert til ni underkategorier og tre hovedkategorier. Prosessen gikk frem og tilbake mel- 
lom deler og helheter flere ganger i tråd med hermeneutiske prinsipper. For validering ble de siste analysefasene parallelt gjennomført av de to andre forskere, hvoretter resultatene kunne sammenstilles, diskuteres og justeres.

Forsker som intervjuet, har vært ansatt i WayBack Oslo i lengre tid, men hadde ikke primærkontakt eller oppfølgingsansvar for medlemmer. Arbeidsforholdet kan likevel ha påvirket deltakerne til å avgi «riktige svar» ut fra hva de anså som forventet, samt ha virket inn på forskerens forståelse. For å redusere denne påvirkningen ble det gjort forberedelser til intervjuene gjennom et dialogmøte med faddergruppen, et pilotintervju med en fadder, kunnskapstilegning gjennom faglitteratur, et kollega-intervju av forsker om forforståelsen, samt dialog om temaet med de andre forskerne.

\section{Undersøkelsesenheten WayBack}

WayBack er en selvhjelpsorganisasjon for tidligere fanger. Flertallet av de som søker WayBacks støtte har sittet gjentagende ganger i fengsel, og mange sliter med rusproblemer. Organisasjonen oppsto i 2002, da en del fanger søkte alternative løsninger for å lette overgangen til livet etter soning. I 2007 evaluerte FAFO WayBack i et «forprosjekt» og konkluderte blant annet at «WayBacks arbeid avdekker et grelt hull i arbeidet til det kommunale tjenesteapparatet og kriminalomsorgen hva angår gjenintegrering» (Hansen 2007).

«Faddere» er betegnelsen på de som har rollen som hjelpere, og «medlemmer» er de som får hjelp. At WayBacks faddere er tidligere straffedømte ser ut til å ha betydning. I WayBacks egen «redskapsbok» har et medlem formulert det på denne måten: «Ved å snakke med andre på WayBack forsto jeg at alle har hatt den samme skyldfølelsen, den samme skammen i seg. Jeg var verken verre eller bedre» (Svennevig 2012, s. 73).

For å sikre at organisasjonen styres av likepersoner, fastslår vedtektene at daglig leder, minst halvdelen av styremedlemmene og ansatte faddere må ha soningsbakgrunn.

WayBacks verdier er redelighet, rusfrihet, solidaritet og kameratskap. Verdiene innebærer at medlemmer må være rusfrie og ikke aktive kriminelle. De må ønske en endring mot et redelig liv, tilstrebe ærlighet og å være et forbilde for andre straffedømte. Kjernevirksomheten er likepersonarbeid med støtte innen områdene familie, nettverk, bolig, økonomi, jobb/skole, i samarbeid med offentlige etater. Likepersonarbeidet defineres slik: «... utveksling av egenerfaringer for at andre i tilsvarende situasjoner kan bruke egne ressurser og muligheter til å styre livet i ønsket retning» (Svennevig 2012, s. 13). Medlemmene får hjelp til å planlegge 
løslatelsen og livet etterpå. WayBack oppretter kontakt med fangene i fengsel, møter dem ved løslatelsen utenfor fengselsporten og fortsetter oppfølgningen.

I tillegg til kjernevirksomheten forsøker organisasjonen å påvirke myndighetene gjennom deltakelse i politiske prosesser og faglige fora. Representanter er engasjerte $\mathrm{i}$ høringer, arbeidsgrupper, referansegrupper, på konferanser m.m. Gevinstene for eks-fanger som går i spissen for dette er store, jf. hjelper-terapiprinsippet: den som hjelper andre er best hjulpet selv (Lebel 2007; Dwyer \& Maruna 2011).

WayBack driver ikke definert behandling. Endringsprosesser fra skam til stolthet er likefullt underliggende tema i miljøet, i erfaringsutvekslinger mellom faddere og medlemmer, samt på faddermøter som omhandler arbeidet med medlemmer.

WayBack er den eneste organisasjonen av fanger for fanger i Norge, som har klart å etablere seg og ekspandere både sentralt og gjennom oppretning av nye avdelinger i norske byer. Frem til 2012 hadde organisasjonen støttet over 1000 medlemmer (Svennevig 2012).

Lignende organisasjoner med tilsvarende virksomhet finnes i andre europeiske land. Den svenske organisasjonen «Kriminellas revansch i samhället» (kris.a.se) har underavdelinger i både Danmark og Finland. I England finnes organisasjonen «Unlock» (unlock.org.uk). Litteratursøk frembrakte kun vitenskapelige studier fra Nord-Irland (Dwyer og Maruna 2013, 2011), samt fra USA (Lebel 2007). Innsatsen som ytes i regi av slike organisasjoner kan beskrives med det talende begrepet «wounded healers» (Lebel 2007).

\section{Teoretisk rammeverk}

I det følgende presenteres teorier og begreper som anses fruktbare som bakgrunnsforståelse og som basis for analyse og diskusjon i et senere kapittel.

\section{Empowerment}

Begrepet knyttes gjerne til bevegelser som den amerikanske borgerrettsbevegelsen, kvinnebevegelser og frigjøringsbevegelser i den tredje verden (jf. Freire 1999; Askheim 2012). Økt bevissthet om undertrykkende økonomiske, politiske og sosiale forhold i samfunnet, og hvordan disse skapte sosiale ulikheter, bidro til en kollektiv innsats av likepersoner med sikte på økt innflytelse og økte rettigheter. En snakker her gjerne om empowerment som motmakt. Bevisstgjøring gjennom dialog står sentralt i Freires pedagogikk. Når den enkelte gjennom dialog med andre får innsikt i sammenhengen mellom egen livssituasjon og ytre forhold i samfunnet, kan dette legge grunn for handling og motmakt. Den enkelte vil 
kunne se sine egne muligheter og livssituasjon, ikke utelukkende ut fra individuell forståelse, hvor en selv alene står ansvarlig for sin situasjon, men også i lys av strukturelle mønstre. Forståelsen innebærer muligheter for å redusere egen opplevelse av skyld og skam. De underpriviligerte vil selv kunne stå frem som politiske aktører. Ideèn var at de skulle opparbeide seg styrke og kraft til å komme ut av avmaktssituasjonen, og motarbeide de krefter som holdt dem nede. Endringen innebar økt makt, kontroll og styring i eget liv. Oppstarten av WayBack og søsterorganisasjoner i andre land kan ses i lys av denne forståelsen.

Empowerment handler både om maktforhold knyttet til gruppe- og samfunnsstrukturer, og om individuelle dimensjoner knyttet til økt innflytelse over eget liv (Askheim 2012). I denne studien inngår empowerment hovedsakelig på individnivå, men også dels på gruppe- og samfunnsnivå.

Kritikk av individuelt empowerment-inspirert sosialt arbeid peker på at tilnærmingen bidrar til å styre individene til sosial orden og ikke være til byrde for andre. Ansvaret for egen velferd pålegges individene og lykkes de ikke, er det deres egen feil. Det frie individet forventes å kombinere selvrealisering og selvkontroll (Askheim \& Starrin 2007; Rønning 2007).

\section{Marginaliserte grupper}

Det er vanlig å betrakte marginalitet som en posisjon i utkanten av samfunnet. Hjemdal, Nilsen \& Seim (1997) betegner marginalitet som en utsatt posisjon. Begrepet må forstås som en bevegelse innen et kontinuum mellom motpolene: total eksklusjon og full integrasjon. Personer som er gjengangere i fengsel er utstøtte og stigmatiserte på grunn av deres handlinger og samfunnets sanksjoner. Hjemdal, Nilsen \& Seim (1997) og Svennevig (2012) beskriver hvordan livet på kanten av samfunnet fører til ustabile, midlertidige og konfliktfylte relasjoner. Fanger betegnes ofte som en (ressurs)svak gruppe, der individuelle ressurser underkommuniseres (Falck 2001).

\section{Skam}

Skam er en følelse som svekker båndet mellom den enkelte og samfunnet, og den har en avgjørende funksjon som sosial kontroll (Lewis 1971, Scheff 2003). «Når vi skammer os, ser vi selvets dobbelte funktionsmåde i fuld aktivitet - vi ser os selv, samtidig med at vi kan iagttage os selv udefra. Selviagttagelsen bliver en basis for angrebet mod selvet» (Weston 2010: 27). Skammen oppstår i det indre, samtidig som den er rettet ut over mot samfunnet. Den skamfulle forventer forakt, ikke medfølelse og omsorg. Sterk skam kan være en hindring for selvutvikling. Dette har sammenheng med at mennesker som relasjonelle vesener, er avhengige 
av nærhet og anerkjennelse av andre mennesker (Honneth 2007). Ved andres avvisning og fordømmelse, kan skammen aktiveres. Fenomener kjent fra fangegruppen som rusmisbruk, avhengighetstilstander og fysiske overgrep, er skambaserte syndromer der skamfølelsen kan være både utgangspunkt og konsekvens. Den som drukner sin selvforakt i sprit, våkner verre til mote (Skårderud 2001).

Sterk skam får mennesker til å trekke seg bort fra offentligheten fordi skam tærer på energien og skaper selvforakt. Tilbaketrekningen kan forstås som en beskyttelse mot å bli mer krenket og ødelagt. Beskyttelsen kan ta overhånd og bli problemet (Skårderud 2001; Scheff 2003). Fangers tilbakefall, ofte kort tid etter løslatelse, kan være en strategi for å beskytte seg selv.

Skammen kan også fungere positivt som en beskyttelse for vår sårbarhet, regulere vår intimitet med andre og dermed bidra til vår tilpasning. Sett i lys av et maktperspektiv (f.eks. Foucault 2007), kan tilpasningen imidlertid også forstås som de utstøttes underkastelse og internalisering av gjeldende sannheter om hva det innebærer å være en kompetent samfunnsborger.

Det er i spenningen mellom hvordan jeg vil bli sett og hvordan jeg føler jeg blir sett at følelsesspekteret mellom skam og stolthet har spillerom. «Skam er idealer som ikke blir innfridd» (Skårderud 2001: 61).

\section{Stolthet}

Stolthet kan forstås som selvrespekt, selvaktelse og god selvfølelse. Stolthet kan dannes når personer og grupper makter å overkomme stempling (Weston 2010). Gjennom å inneha selvrespekt vil en kunne håndtere følelser som svakhet, fiasko, skam og skyld uten at den indre balansen utfordres i betydelig grad. Snarere enn en indre terroriserende kritiker har man en indre, trøstende stemme (Weston 2010). Stolthet kan her ses som en parallell til helse, definert som «en ressurs som gir mennesker styrke til å fungere og motstandskraft til å stå imot påkjenninger» (Mæland 2012:25). Opplevelsen av stolthet er en tendens til å kringkaste ens suksess til verden, og den glade følelsen som făr oss til å ville delta offentlig (Britt \& Heise 2000).

\section{Avvik og stigma}

Teorier om stigma og stempling har vært betydningsfull for forståelsen av psykisk sykdom, rusproblemer og kriminalitet som avvik fra sosiale normer. Edwin Lemert (1951) fremmet den sosiale reaksjonens betydning for å holde et avvik stabilt over tid (Norvoll 2013). Lemert deler opp avvik i primær og sekundær avvik. Primæravviket er den opprinnelige avvikende handlingen eller karakteristikken av den. Andres reaksjon fører til sekundæravviket, - den reaksjonen den av- 
vikende har på reaksjonen. Avviket kan på denne måten forsterkes. Gjennom andres reaksjon kan avviket gå inn i en syklus som medfører selvoppfyllende profetier (Lemert 1951). Inspirert av blant annet Lemert, utdyper Goffman i sin avhandling «Stigma», belastningen som kan følge av å leve med en stigmatisert fortid når menneskene rundt en vet, men også når de ikke vet.

Freire (1999) poengterer at de undertrykte selv kan bli nye undertrykkere. De som har vært utsatt for skamløs atferd, kan selv bli en «skammer» som krenker andre. Dette kan forstås som forsvar mot den tause, men sterke underliggende skammen man bærer i seg, den benektede skammen (Skårderud 2001).

\section{Eks-fangenes skildringer}

I dette kapittel blir funnene som fremkom i analysen presentert ved hjelp av syv kategorier. Hver kategori blir visualisert via sitater i tråd Brinkmann og Kvale (2012). Kategoriene blir gjenstand for diskusjon i neste kapittel.

\section{Marginalisering som prosess}

Marginaliseringsprosessen kan ha startet allerede i barndommen og blitt forsterket av miljøet man kom inn i. Flere av deltakerne beskriver en oppvekst, der foreldre eller søsken hadde rusproblemer eller alvorlig sykdom og følgelig begrenset oppmerksomhet og omsorg å gi. En deltaker forklarte hvordan han følte seg som en outsider: «... fordi man hadde ingenting på stell. Man kom på skolen uten ski på skidagen, uten leksene gjort og uten matpakke, gikk i de samme klærne i en uke». Flere vokste opp i ustabile familieforhold. En vokste opp i fosterhjem og en annen bodde i perioder på barnehjem. Flere deltakere beskriver følelser som skam og ensomhet $i$ en krevende barndom der de ikke hadde noen å snakke med. Dette medvirket, slik de ser det, til at de ble «vanskelige barn» og utagerende tenåringer som skilte seg ut fra jevnalderne. De søkte fellesskap med likesinnete eldre venner i miljøer i randsonen av samfunnet. Den nye tilhørigheten i tillegg til rusmidlene, dempet smertene og fjernet tomheten.

Brorparten fikk en rolle som ga status og følelsen av at andre trengte dem: «Man var jo i en posisjon. Alt annet det var hobby.» I perioder opplevde de gleden av å ha rikelig med penger.

Etter år i det kriminelle miljøet og en rekke straffedommer, har deltakerne klart å slutte med rus og kriminalitet. De har forlatt miljøet de tilhørte, og ensomheten kan oppleves slående:

«Det var jo en ensom tid, hvor man fikk smake litt på den illusjonen av tilhørighet og samhold og lojalitet, og det man på en måte tror finns der ute.» 
Deltakerne gir i hovedsak inntrykk av at skammen ikke er påtrengende så lenge man er i fengsel. En deltaker sier:

«Inne i fengselet, så var jeg i et trygt miljø. Det miljø klarte jeg å ferdes i. Det var ikke noe problem etter mange år. Men da jeg kom til å stå alene ute i samfunnet, det var da skammen kom, ja følelsene i det hele tatt, masse følelser.»

Flere gir uttrykk for at de først har gjort opp for seg etter soning, ved å bli «et annet menneske» og gjennom «å gjøre gode gjerninger.»

\section{A henge etter}

I møte med samfunnets krav og forventninger kan kontrastene bli store. En deltaker forklarte:

«... og betjentene forteller omtrent hvor tingene skal ligge på cellen din, og når du skal gå på do, og når du skal dusje og alt sånn. Så blir det annerledes når du kommer ut og faktisk skal begynne å tenke selv.»

Står man alene uten arbeid, bolig eller annen kapital, kan skambøren kjennes bokstavelig:

«Jeg hadde brent alle broer da. (...) for det er jo veldig mange som detter av på veien, når dem går der og bærer alt for mye poser og bagger, - og så gir opp bare av bæringen. For hvor skal du gå hen? Du er lissom så ensom da.»

Deltakerne skildrer at de kommer til kort på flere områder samtidig; sosialt, materielt, i forhold til bolig, arbeid og utdanning, etc. Det er akkumulering av flere slike problemområder som ser ut til å overvelde og bidra til skam. En deltaker sa: «Jeg har egentlig dettet ut på alle områder».

Deltakerne forteller at de møter samfunnets mistro og stigma: «Du får et stempel, altså du har vært kriminell og da er du det, da er det med deg». Samtidig må de takle undertrykte følelser i forsøket på å bygge ny identitet:

«I underbevisstheten min, så er jeg utstøtt (...) det er en blanding av skam og skyld (...) det er noe som vokser, ikke sant. Skjult og underbevisst, så kommer skammen, enda jeg ikke synes det er riktig den skal være der. For det er dem du skal overbevise, altså dem som er i samfunnet.» 


\section{Bevisstgjøring}

Veien til det nye livet betinger at man lærer seg å forstå egne følelser som frykt og skam. Deltakerne har hatt behov for å gjennomgå bevisstgjørende prosesser for å få innsikt til å kunne stå i sårbare livssituasjoner:

«Du kan ikke leve med garden opp. Du må tørre å være sårbar, tørre å være lei deg og sånne ting. (...) Det å plutselig tørre å være engstelig og urolig for fremtiden, og kjenne at man gruer seg til det man ikke vet kommer, det var en vanskelig læringsprosess.»

«Vi får ikke fikset ting, gjort er gjort, men du må lære deg å berøre disse tingene som du har lagret. Fordi når du kommer hjem og du kanskje er i jobb og alt går bra, så skjer det noe. Kanskje moren din dør. Kanskje du mister din kjære, kanskje blir du akutt syk ... Og da går det hull på alt, det gjør som regel det, og da kommer det en flodbølge av de tingene du bare har lagret. Så er det det som feller deg, fordi du ikke er forberedt.»

Betydningen av samtaler med profesjonelle under soningen ble fremhevet av noen deltakere.:

«Min behandler, hun stakk på en måte hull på alt det der, og vi pratet mye om ting jeg egentlig ikke opplevde som vanskelig, men når jeg fortalte henne det, og jeg så hennes reaksjon, så skjønte jeg at det måtte vært det.»

Andre deltakere hadde hatt nytte av en psykolog, av NA (anonyme narkomane), og en gestaltterapeut. Alle vektlegger WayBacks støtte i deres prosess, og i særdeleshet samtalene med faddere. Det at fadderen har gjennomlevd lignende prosesser, beskrives som avgjørende:

«På mange måter så er jeg ganske lik Per (fadder) da. Det er veldig motiverende og trygt, og jeg hører jo mye på hva Per sier. Jeg vet at han har hatt det, og har det, også sånn som jeg har det. Hva gjorde han, og hva tenker han, jeg synes det er veldig nyttig.»

Studien viser at deltakerne har slitt med dårlig samvittighet eller skam. Det gjelder eksempelvis i forhold til aldrende foreldre, barn eller hunder som ikke er blitt ivaretatt, gode arbeidsgivere og venner som man har sviktet, eller personer man har behandlet dårlig. De skamfulle følelsene hjemsøker nå flere av deltakerne. En deltaker uttalte:

«Jeg kjente at jeg var sliten, sånn dårlig sliten, og jeg fant ut at jeg kan ikke bære med meg alt. Det var så mye negativ energi fra fortiden. Det å bære med seg denne skyen av uoppgjorte ting og gamle fighter og opplevelser, tok veldig, veldig mye krefter.» 
I tillegg til å bearbeide disse temaene gjennom samtaler med andre, velger mange å be om tilgivelse hos dem det gjelder. $\AA$ be om tilgivelse beskrives som «... en sånn der følelsesting som gjør at man føler seg liten, svak og ynkelig når man gjør det». Flere forteller om «stolte og befriende» følelser som oppstår når de får tilgivelse. I de tilfeller der de ikke blir tilgitt, kan selve intensjonen med å gjennomføre handlingen, å be om tilgivelse, likevel bidra til både selvforsoning og underbygning av et redelig selvbilde. Studien viser at der deltakernes ønske om tilgivelse ikke er mulig grunnet den andres død, kan det være krevende å leve med samvittigheten. Dette gjelder spesielt der man selv har påført døden eller medvirket til den. En deltaker valgte å be om tilgivelse overfor sønnen til en avdød arbeidsgiver som han hadde sviktet. En annen deltaker forsøker å gjøre opp for tidligere mangelfult hundehold ved å sørge ekstra godt for sin nye hund.

\section{A giøre en innsats for andre}

Fem av respondentene er aktivt engasjert i å gjøre en innsats for andre. De løfter fram betydningen av egen-healingen $i$ dette.

«For dette er jo det som gir meg mest mening, spesielt når det gjelder unge gutter 20-25 år som klarer å snu på livet sitt, og få være med på den reisen. Når de kommer og betror seg til meg om følelser, sitter og prater om at de har vært sinte eller skammer seg eller hva enn det måtte være, så er det veldig stort. (...) Hvis det går bra, da gir det jo mye mer enn en lønnspose.»

«I mitt tilfelle da, så har jeg sonet mange år i fengsel, men likevel har det vært bedre for meg å jobbe frivillig på WayBack eller på nærmiljøsenteret. Sånne ting at jeg har gjort noe uegennyttig, pille søppel når jeg går tur med bikkja mi, som ingen ser. Det er noe som leger meg på en eller annen merkelig måte.»

En deltaker som støtter to personer med rusproblemer i nabolaget, forteller at det samtidig hjelper ham selv: «Jeg har de menneskene rundt meg (...) jeg renser meg selv med å prate med de.»

\section{Sammenheng i tilvcerelsen}

Deltakerne ser ut til å ha oppnådd økt stabilitet og mer sammenheng i tilværelsen. De gir uttrykk for at dette hemmer skammen og fremmer stolthet. En deltaker sier:

«De tingene jeg har i livet mitt nå, dem betyr så inderlig mye. Jeg tror at når man ikke har noe man er redd for å miste, så er det vanskelig å ta vare på seg selv og. Da snakker vi om de her tingene som gjør deg hel.» 
Parallelt med bevisstgjørende prosesser, har deltakerne søkt fotfeste på avgjørende områder. Nær tilknytning til familie, venner og/eller hund trekkes frem som vesentlige faktorer. Alle deltakerne har bygget opp noen nære relasjoner, i tillegg til deres tilknytning til WayBack eller andre nettverk. Flere beskriver dette som utslagsgivende for at de ikke faller tilbake til kriminalitet, eksempelvis: «Jeg har fått så stort nettverk at jeg tror ikke det er noe fare for noe lenger».

De fleste deltakere mener at en betalt og gjerne meningsfull jobb har stor betydning. Men også frivillig engasjement i organisasjoner beskrives å kunne veie opp for en betalt jobb. To av de tre som har trygd som inntekt gir uttrykk for at den lave inntekten begrenser deres fremtidstro og muligheter. Den ene fremhever at han ikke er i stand til å gi sine barn levekår som når opp til forventninger i samfunnet.

\section{Forsoning}

Ved å omsette de verdier en ønsker å representere til handling, kan man vise at man tar sitt nye selv på alvor. «Det handler jo om å kunne se seg selv i øynene om morgenen, når man står opp» forklarer en deltaker. Flere deltakere beskriver hvordan omgivelsenes fordømmelse og stigmatisering får mindre innflytelse etter hvert som selvfølelsen og selvtilliten øker:

«Jeg har gjort veldig mye i WayBack regi, men det er en ting. Jeg har gjort mye utenfor også, for å gjøre opp for meg i samfunnet. Så jeg føler at det ikke er noe noen kan ta meg for lissom. Og hvis noen vil dømme meg og være sånn, så okey, så får dem gjøre det. Jeg trenger ikke dem menneskene i livet mitt. Sånn er det bare.»

Historiene om forsoning har flere sider. En side handler om skader man har påført andre, mens en annen side gjelder de krenkelser man selv har blitt utsatt for. En deltaker utsatt for grove overgrep beskriver hvordan han har forsonet seg ved å fraskrive seg skyld i hendelsene. Han er også bevisst på «at man kan ikke la seg felle av alt som har skjedd». En annen deltaker følte han fikk oppreisning da han «tok igjen» overfor overgriperen. Andre faktorer som deltakerne beskriver som avklarende og formildende omstendigheter i deres selvforståelse er: Omsorgssvikt som et dårlig utgangspunkt, rusavhengighet, ugjerningene var ikke intenderte, og det å ha vært en person som «ikke var stygg med andre» $\mathrm{i}$ det kriminelle miljøet. 


\section{A bli anerkjent}

Undersøkelsen viser at det har stor betydning for deltakerne å kunne stå frem uten å tildekke fortiden i det nye redelige livet. Men en slik åpenhet er en krevende øvelse. En deltaker sa:

«... når jeg liksom kom ut og snakket med andre mennesker, så visste jeg faen ikke, hva jeg skulle snakke om, og åssen jeg skulle uttale meg. Jeg følte jeg bare kunne snakke om en ting, og det var jo om kriminalitet og rus da.»

WayBack beskrives som en viktig treningsarena i overgangen. En deltaker sier: «Det beste jeg gjorde var jo å gå inn døren der oppe på WayBack». En annen forteller:

«... det ga meg akkurat det jeg trengte, i den forstand at det var en plass med rammer, som gjorde at det var trygt å være der. (...) hvis man ville gjøre noe galt, så ble det veldig mye arbeid for å si det sånn. Så var det jo mye lettere å la være da.»

Skrittene videre fra WayBack til arbeid og egen bolig, fremstiller deltakerne som nye terskler som skal forseres: «Hva vil andre tenke, duger man der ute i samfunnet, vil man klare å stå på egne bein». En deltaker forteller at han følte seg «som en liten unge som hang langt etter». Men når han kom i jobb, fikk han det beviset han trengte for å skjønne at han var god nok.

Alle deltakerne i denne undersøkelsen velger bevisst å fortelle menneskene i deres omgivelser om deres fortid. De få tilfeller der deltakerne ikke har valgt åpenhet, omhandler hensynet til familie, møter med fremmede, møter med potensielle kjærester og arbeidsgivere.

Tre av deltakerne har brukt deres erfaringsbaserte kunnskap i offentligheten gjennom media, foredrag, kurs og lignende. De poengterer at dette har medvirket til å fjerne skamfølelser og fremme deres forsoning med fortiden, eksempelvis:

«... jeg bruker det når jeg sitter i brukerrådet, - sånne ting. Ja, og jeg har stått på nyhetene og fortalt historien min, så jeg har forsonet meg med det på en måte.»

De forteller at de har høstet mye anerkjennelse fra tilhørere og i deres egne miljøer for innsatsen.

Undersøkelsen viser at anerkjennelse kan foregå på forskjellige relasjonelle områder, og ikke må inkludere et større publikum. Det kan også handle om å mestre foreldrerollen for en far, som ikke selv hadde foreldre som mestret rollen like godt: 
«... og så er det der at Birte alltid spør meg, hva vi skal ha til middag i dag. Da føler jeg også en god følelse, fordi det ville ikke et barn si, hvis det ikke fikk middag hver dag.»

\section{Diskusjon}

Med utgangspunkt i studiens funn, drøftes straffedømtes muligheter for endring fra skam mot stolthet etter soning. Det tas utgangspunkt i samfunnsmessige forhold som opprettholder skammen og motvirker empowerment og integrering. Videre diskuteres forhold som har betydning for den enkeltes empowermentprosess.

\section{Samfunnets mangel på støtte}

Deltakerne opplevde situasjonen ved løslatelsen som utfordrende. Andres reaksjoner eller kanskje i like stor grad mangel på reaksjoner når en kommer ut av fengsel og er hjelpetrengende, kan oppleves som stigmatiserende og avvisende, og fremme skamfølelser. Undersøkelsen viser at den enkelte er avhengig av støtte for å kunne stå imot frykt, skam og rustrang. Manglende inkludering kan bidra til å gjøre veien tilbake til kriminalitet kortere jr. Lemerts avviksteori (1951).

Aron Antonovsky (1992) pekte på at en betydningsfull helsefremmende faktor er når ens livssituasjon kan oppleves forståelig, håndterbar og meningsfull (Sence of Coherence - SOC). Undersøkelsen viste at en slik følelse av sammenheng i tilværelsen (SOC) var fraværende for majoriteten av deltakerne i tiden etter soning. Fraværet av SOC synes å bidra til at deltakerne følte seg fremmedgjorte i samfunnet.

Deltakernes beskrivelser av å stå utenfor fellesskapet avdekker viktigheten av integreringstiltak. Allerede i 1841 uttalte straffeanstaltkommisjonen at «man må ikke forlade Fangen i det kritiske Øieblik, han derfra løslates», med tilsvarende begrunnelser som vi kjenner i dag (Falck 2015: 7). Falck og Riksrevisjonen (2014) peker på at et mindretall av fanger med rusproblemer blir fulgt opp etter løslatelse. Frivillige organisasjoner har blitt fremhevet som viktige bindeledd i tilbakeføringen til samfunnet, men satsningen på organisasjonene reflekteres bare med 0,6\% i kriminalomsorgens budsjett (Falck 2015).

\section{Loslatt til frihet?}

Undersøkelsens deltakere opplevde tiden etter løslatelse som en ny type avstraffelse, mer enn en positiv frihet. Filosofen Arne Johan Vetlesen peker på at konkret realisering av frihet bestemmes av samspillet mellom individet og dets omgivelser (2009). En eks-fange i WayBack uttrykte seg slik om friheten: «Det er ingen frihet i det tomme rom». Om man står svakt sosialt, økonomisk, i arbeidsmarked, boligmarked, kulturelt og politisk, kan det virke umulig å realisere frihe- 
ten. Stigmatisering er ikke bare et spørsmål om ydmykelse og avvisning. Problemet dreier seg også om lav status og manglende makt (Fossum 2003). Å stå utenfor fellesskapet gir ingen frihet.

\section{Dialogenes betydning for bevisstgjøring og empowerment}

Deltakerne i undersøkelsen beskriver på ulike måter å ha stått i pinefulle kamper i forsøkene på å imøtekomme det ordinære samfunnet. Funnene viser at endringen/løslatelsen kan skape frykt og skam. Skam kan være mangelen på delte opplevelser (Skårderud 2001) og kan motvirkes ved at gruppen diskuterer marginaliseringen gjennom samvær og samtaler og gjennom terapeutisk behandling. Frykt aktiverer mennesker og forbereder dem til å gjøre noe. Det dysfunksjonelle er at prosessen gjør folk sårbare, de kan velge inaktivitet framfor å kjempe (Britt \& Heise 2000). Alternativt kan eks-fanger flykte tilbake til det livet de kjenner, til rusen og det kriminelle miljø.

$\AA$ fastholde en atferdsendring over tid er ofte vanskeligere enn selve endringen (Mæland 2012). Funnene viser at tilhørighet til et nettverk av likepersoner oppleves som støttende og kan øke sjansen for å lykkes. Endring tar tid. Det er ingen raske løsninger. Gjennom gjensidig erfaringsutveksling, kan følelser av skyld og skam langsomt vendes til livsmot og stolthet. I samarbeidet med medlemmene er fadderne ikke opptatt av hva den enkelte har gjort, men hva han ønsker å gjøre fremover (Svennevig 2012). Denne tilnærmingen kan signalisere anerkjennelse av medlemmene som fullverdige mennesker med et langt større potensiale enn «diagnosene» som straffedømt og rusmisbruker kan tilsi. Det formidles tro på menneskets iboende ressurser og vilje til å gjøre det gode. Anerkjennelsen kan forstås som en forløsende helsefremmende faktor, et skritt mot å endre synet på seg selv som uverdig til å bli «emosjonell empowered» (Britt \& Heise 2000). WayBack fremhever prinsippet slik: «Vi er ikke stolte av historiene våre, men vi er stolte av at det er historie» (Svennevig 2012: 44).

Det formidles store forventninger til mennesker i en sårbar gruppe. Man kan anta at det kan oppleves skamfullt for de WayBack-medlemmer som ikke lykkes, til tross for at de har fått hjelp av rollemodeller. Hvordan WayBack reagerer på medlemmers tilbakefall kan tenkes å ha avgjørende betydning for om avviket forsterkes (jf. Lemert 1951).

Bevisstgjørende dialoger kan være avgjørende for frigjøring (Freire 1999). Dialogen innebærer makt og kraft til å bygge opp eller bryte ned (Løgstrup 1999). Faddere som likepersoner kan ha bedre muligheter for å oppnå fordomsfrie, likeverdige møter med fangene, enn profesjonelle hjelpere. Fadderne synes å fremstå som modeller og levende eksempler på at det går an å komme ut av «offerrollen» 
og oppnå positiv endring. For mange kan dette være den første spire til håp som gir kraft til videre handling. Hjelperens egenopplevelser av smerte bidrar til at en kan bli en effektiv hjelper (Jackson 2001).

\section{Hjelper-orientering}

Analysen viser at deltakerne finner det meningsfullt og stolthetsfremmende å bruke sine egne erfaringer til å gjøre en innsats for andre. De som hjelper andre gjennom organisasjonsarbeid, lønnet eller ulønnet, synes å oppleve lønnsinntekt som mindre betydningsfullt.

Å kunne være hverandres rollemodeller er en viktig endringsfaktor. Personer som havner i randsonen av samfunnet er ofte selv mottagere av omsorg (Langeland 2014). Derfor kan det være utslagsgivende å bevisstgjøre deres evne til å hjelpe andre. Betydningen av egne sosiale bidrag kan styrke opplevelsen av mening og stolthet. Funnene i vår undersøkelse samsvarer med studier av eksfangeorganisasjoner i USA og Nord Irland som vektlegger at det kan virke mer integrerende å gi hjelp enn å motta hjelp. Det kan gi status og gjøre hjelperen til et viktig medlem $i$ hans eller hennes miljø (Lebel 2007; Dwyer \& Maruna 2011).

Funnene i vår studie utdyper fordelene ved å hjelpe andre: Det bidrar positivt $\mathrm{i}$ identitets- og forsoningsprosesser og fremmer stolthet. Det oppleves tilfredsstillende å kunne gi noen den hjelpen en ikke selv fikk tidligere i livet. Det kan bidra til at en kan gjøre opp for seg ved å gi noe tilbake til andre. Det gir mening til den delen av livet som ellers kan oppfattes som både meningsløs og forspilt. At erfaringene har blitt omdannet til kunnskap som er nyttig for andre, medfører stolte følelser. Å sette ord på følelser overfor andre, innebærer en stadig bevisstgjøring hos en selv som igjen er en hjelp til å navigere i gråsoner for å holde seg på den rette stien.

Det synes som det å hjelpe andre bidrar til å reparere den dype skammen i en selv; smerten ved å se seg selv som en som ikke fortjener å bli elsket (jf. Skårderud 2001).

\section{Fortelle om fortiden - eller ikke}

Studien viser at skammen forsterkes i møte med ukjente utenfor fengselet. Det er komplisert å skjule fortiden og samtidig bygge tillitsfulle relasjoner i et nytt redelig liv. Skammens vesen handler om tildekking, og veien mot stolthet innebærer å være ærlig, - å kunne se seg selv og andre i øynene.

Den som «passerer» inn i de normales rekker utsetter seg for ubehaget ved å erfare hva andre mennesker virkelig tenker om personer «av hans slag», før han gir seg til kjenne. Han utsetter seg også for andres ubehagelige reaksjoner når han 
først vedkjenner seg sin fortid (Goffman 1975). Det har ofte sin pris å bryte et tabu. Studien viser at åpenhet om fortiden og å be om tilgivelse kan være svært krevende øvelser. Tidligere fanger vil stå i daglige kvaler mellom å fortelle eller ikke, til de får fotfeste og sammenheng i tilværelsen. Man må justere og tilpasse sin fremtreden til hver enkel kontekst, der man møter andre mennesker (Goffman 1975). Funnene viser at dette foregår parallelt med andre krevende psykologiske prosesser i streben mot å skape en ny identitet. En kan da være ekstra sårbar for avvisninger. Straffedømte må kontinuerlig ta stilling til om de vil tildekke fortiden eller risikere negative reaksjoner ved å fortelle om sin fortid.

Deltakerne i undersøkelsen fant støtte hos likepersoner i slike prosesser. Undersøkelser fra Nord Irland av Dwyer \& Maruna (2011) viser at grupper med tidligere fanger ble skapt nettopp for å kunne konfrontere slike utfordringer. Gruppemedlemmene pekte på at det er felles bånd mellom tidligere straffedømte, og å hjelpe «brødrene» var avgjørende for gruppeidentiteten. I vår studie velger alle deltakerne å fortelle menneskene i deres daglige omgivelser om sin fortid. På denne måten omgir de seg med mennesker som anerkjenner dem og gir dem frihet til å være seg selv. For noen innebærer valget et begrenset nettverk, hvorav de fleste står i en lignende situasjon.

\section{Betydning av brukerstyring}

En suksessfaktor for WayBack er at virksomheten er brukerstyrt, av og for fanger. Gjennom samarbeid om felles mål og virkemidler, kan det utvikles følelser av eierskap. Bevisstgjøringsprosesser kan skape fundamenter av kollektiv selvfølelse, selvtillit og ansvar. Samtidig skapes det kompetanse. Utviklingen av organisasjonen har foregått langsommelig med frem- og tilbakeskritt, men på eksfangenes egne premisser (jf. Freire (1999). Prosessene har kunnet pågå uforstyrret av eksperter, hvilket er en viktig forskjell fra brukermedvirkning i omsorgssektoren: «Den makten som ligger i fagfolkenes ekspertkompetanse, kan i seg selv forstyrre brukermedvirkning, fordi brukeren kanskje regner fagkompetansen for så viktig at egen kompetanse ikke tilkjennegis, eller at fagfolkene selv anser egen kompetanse som viktigere enn brukerens og kanskje heller ikke etterspør denne» (Tveiten, 2007, s. 32). Dette kan føre til underdanighet, der man ikke våger å ta egne initiativ og handle i frykt for å gjøre feil. I stedet gjør man som man tror forventes, men med begrenset handlekraft og initiativ. «Skammen senker selvtilliten, minsker viljen til å handle og ta egne initiativ» (Starrin 2007). 


\section{Offentlighet og stolthet med organisasjoner i ryggen}

Studien viser at deltakere som har eksponert seg jevnlig i offentligheten, har fått redusert skam og forsonet seg med fortiden. De tillegger hovedårsaker som diverse opptredener i media, foredrag, brukerfora og lignende, der de også snakker om personlige prosesser. Emosjonell empowerment peker på at stolt atferd finner sted i det offentlige rom i motsetning til skam som genereres og forsterkes gjennom isolasjon og tildekking (Britt og Heise 2000). Hvis man avdekker en skam offentlig, kan handlingen produsere stolthet, selv om man ikke følte stolthet der og da. Resultatet blir ofte at personen assosierer offentlig handling med stolthet.

Deltakerne finner også mening $\mathrm{i}$ å bidra til folkeopplysning og redusering av stigma ved å synliggjøre menneskene bak «de kriminelle monstre». «Synliggjøring er nødvendig for å demme opp for frykt og myter, som igjen forsterker en underordnet posisjon» (Hjemdal, Nilsen \& Seim 1997, s. 30). En deltaker har opplevd hets og negative reaksjoner etter å ha opptrådt offentlig. I slike tilfeller kan det være avgjørende å ha et støttende og anerkjennende nettverk rundt seg.

Kontrollteori peker på at jo større investering individet har gjort for å involvere seg og knytte bånd til andre mennesker og fellesskap, desto dyrere blir det å bryte båndene (Hirschi 1969). Om man ikke har tilhørighet til et fellesskap, får man større rom for å skjøtte egne interesser som kan stride mot etablerte samfunnsnormer. Tidligere fanger er avhengige av å knytte bånd til fellesskap i samfunnene rundt dem for å kunne utvikle emosjonell empowerment og for å bli integrerte (Guy 2011). Organisasjoner kan fungere som en katalysator og ett springbrett. Kollektive tiltak kan samtidig styrke samfunnets muligheter til å løse utfordringer og ta kontroll over utviklingen (Mæland 2012). Studiene av eksfangegrupperinger i Nord Irland, viste at mange grupper utviklet seg til å bli agenter for både politisk og sosial endring med en stigma-mestrende orientering. På individnivå ligger potensialet for å utvikle pro-sosiale selvkonsepter og identiteter gjennom meningsfulle fellesskap. (Dwyer \& Maruna 2011). Flere forskere påpeker «at brukerorganisasjonenes betydning for at brukerne kan komme ut av sin avmakt har vært tillagt liten vekt i det helse- og sosialfaglige arbeid, og studier har vist at sosialarbeidere synes det er skremmende å gå ut av tradisjonelle profesjons- og behandlerroller for å møte klientene på slike arbeidsformer» (Askheim 2012: 25).

\section{Anerkjennelse}

Ifølge Aksel Honneth dreier dannelsen av sosiale bevegelser seg om kampen for anerkjennelse, for å øke medlemmenes sosiale verdi eller anseelse (2007). Honneth viser at fravær av anerkjennelse kan medføre at mennesker opplever seg 
krenket på ulike måter. Anerkjennelse inneholder både erkjennelse og tilstedeværelse $\mathrm{i}$ tanke og $\mathrm{i}$ handling. Det er tale om tidskrevende prosesser når man skal se og bli værende hos den som trenger det. Honneth bygger sin forståelse av anerkjennelse innenfor tre interaksjonssfærer: privatsfæren, den rettslige sfære og den solidariske sfære. I privatsfæren i familie og parforhold, danner kjærligheten og anerkjennelsen grunnlag for at en kan få selvtillit og inngå i nære relasjoner, så vel som å opptre selvstendig i det offentlige liv. I den rettslige sfære kan anerkjennelse oppstå når mennesker aksepterer hverandre som fullverdige medlemmer av samfunnet med alle de rettigheter og plikter dette medfører. Denne type anerkjennelse kan danne grunnlag for utvikling av selvrespekt og stolthet. Den solidariske sfære innebærer mulighet til anerkjennelse av vår særegenhet som uerstattelige, unike individer som bidragsytere i fellesskapet. Anerkjennelsen skjer her på bakgrunn av særlige kvalifikasjoner, og får vi denne form for anerkjennelse, kan vi utvikle selvbildet (Honneth 2007).

Ingen av disse anerkjennelsesformer skal forstås som statiske. Til hver av sfærene motsvarer en rekke krenkelser. Manglende anerkjennelse kan eksempelvis resultere i nedverdigelse, fornærmelse, forakt, usynliggjørelse, - følelser som alle kan relateres til skammen. Skal vi oppnå selvrealisering individuelt og sosialt, forutsetter det anerkjennelse på de tre nevnte områder (Honneth 2007).

Som undersøkelsen viser har mange straffedømte oppnådd lite anerkjennelse i den private sfære på grunn av manglende omsorg i oppveksten. Mange løslates til lite anerkjennelse i den rettslige sfære, uten tak over hodet og penger til livets opphold, og i den solidariske sfæren kan det skorte på reelle muligheter for selvrealisering fordi eks-fangene ikke har den livslange læring og kompetanse som ofte kreves i et moderne samfunn med økt individualisering. Det etterlater lite rom for anerkjennelse av tidligere straffedømtes prestasjoner og ferdigheter som verdifulle for samfunnet. Tvert imot er deres selvfølelse og selvtillit ofte lav blant annet på grunn av gjentagende fiaskoer og krenkelser.

\section{Konklusjon}

Bevegelsen fra skam mot stolthet i livet etter soning er en prosess som inneholder en lang rekke aspekter. Denne studien viser til et begrenset utsnitt av dem. Erkjennelsen av at bevegelsen mot et redelig liv er en høyst krevende prosess, fremstår som en viktig suksessfaktor for de tidligere fanger i denne undersøkelsen. Erkjennelsen innebærer at den enkelte må tåle å stå ustøtt og ta imot hjelp over tid. Det kan være litt lettere, der en kan omgi seg med et anerkjennende nettverk av likepersoner. Undersøkelsen viser samtidig at hver av deltakerne har individuelle løp med variasjon av hvilke faktorer som er mest virkningsfulle. 
Resultatene fra denne studien vil kunne ha relevans for andre grupper med betydelige stigma. Sammensettingen av mange elementer fører til marginalisering og følelser av skam. I denne studien ble skammen aktivert i møte med samfunnet utenfor fengselet. Selv ikke fundamentale forutsetninger for et menneskes fotfeste; bolig, penger å leve av og sosial støtte er klart ved løslatelsen. Når tidligere fanger søker hjelp og organiserer seg i egne organisasjoner, kan det forstås i lys av at velferdsstatens tiltak ikke oppleves som tilstrekkelig. Eks-fangers reduserte muligheter til å endre konteksten begrenser de reelle utsikter til integrering. Anerkjennelse bør også inkludere rettferdighet og omfordeling innen en rettslig og solidarisk sfære.

Studien har vist hvordan likepersonarbeid kan bidra til anerkjennelse og styrke empowerment $\mathrm{i}$ integreringsprosessen. Bevisstgjørende dialoger og et støttende nettverk viste seg sentralt $\mathrm{i}$ endringsprosessene for å kunne mestre hele følelsesspekteret, og som grunnlag for forsoning.

Selv om marginalisering foregår på flere områder, kan det å få oppleve anerkjennelse og stolthet i en rolle innenfor et bestemt område veie opp for mye. Studien viser hvordan det å bruke egne erfaringer til å hjelpe andre, mestre å være foreldre, mestre andre relasjoner, samt mestre å opptre i offentlighet, kan tilføre mening og stolthet.

\section{Noter}

1. Gitte Svennevig, fagutviklingskonsulent i Seksjon oppfølging, Kirkens Sosialtjeneste. Sosionom med masterutdanning $i$ helse og empowerment. Tidligere faglig leder i WayBack, stiftelsen Livet etter Soning. Interesseområder er likepersonarbeid og brukerstyring. Andre relevante publikasjoner: «WayBack - Det er aldri for tidlig å angre» (2012), artikkelen «Ex-fanger hjelper hverandre» (Fontene 2014), samt «Fangers opplevelser av skam og stolthet etter soning» (mastergradsavhandling 2015).

2. Magne Haukland, Førstelektor, Høgskolen i Oslo og Akershus, Fakultet for helsefag, Institutt for sykepleie og forebyggende arbeid, videreutdanning i psykisk helsearbeid, og master i helse og empowerment. Cand.sosiol fra Universitetet i Oslo. Interesseområder er helse/psykisk helse, makt, og sosial ulikhet.

3. Dag Willy Tallaksen, Førstelektor, Høgskolen i Oslo og Akershus, Fakultet for helsefag, Institutt for sykepleie og forebyggende arbeid, videre- og masterutdanning i psykisk helsearbeid. Av utdanning har han Embetseksamen i Sykepleievitenskap fra Universitetet i Oslo. Interesseområder er psykisk helsearbeid og selvmordsforebygging. 


\section{Referanser}

Antonovsky, A. (1992). The Salutogenic model as a theory to guide health promotion. Health Promotion International, 11(1), (s. 11-18).

Askheim, O.P. (2012). Empowerment $i$ helse og sosialfaglig arbeid: Floskel, styringsverktøy eller frigjøringsstrategi. Oslo: Gyldendal akademisk.

Askheim, O.P. \& Starrin, B. (2007). Empowerment - et moteord? I O.P. Askheim \& B. Starrin, (Red.) Empowerment i teori og praksis (s.13-20). Oslo: Gyldendal akademisk.

Askheim, O.P. \& Starrin, B. (2007). Utfordringer innenfor det sosialfaglige arbeidet. I O.P. Askheim \& B. Starrin, (Red.) Empowerment i teori og praksis (s .189-199). Oslo: Gyldendal akademisk.

Brinkmann, K. \& Kvale, S. (2012). Det kvalitative forskningsintervju (2. utg.) Oslo: Gyldendal Akademisk.

Britt, L. \& Heise, D.R. (2000). From Shame to Pride in Identity Politics. I S. Stryker, T.J. Owens, and R.W. White (Red.), Self, Identity, and Social Movements (s. 252-268). Minneapolis: University og Minnesota Press.

Dwyer, C.D. (2013). Sometimes I wish I was an «ex» ex-prisoner: identity processes in the collective action participation of former prisoners in Northern Ireland. Contemporary Justice Rewiew, (16)4. (s. 425-444).

Dwyer, C.D. \& Maruna, S. (2011). The role of self-help efforts in the reintegration of «politically motivated» former prisoners implications from the Northern Irish experience. Crime Law Soc Change, (55), (s. 293-309). Doi:10.1007/s10611-011-9284-7.

Falck, S. (2001). Forskningens forhold til svake grupper. I M. Sandbæk (Red.), Fra mottaker til aktør: Brukernes plass i praktisk sosialt arbeid og forskning (s. 282-294). Oslo: Gyldendal Akademisk.

Falck, S. (2015). Tilbakeføringsgarantien som smuldret bort: Mellom kriminalomsorg og kommunale tjenester. Tiltaksbro, systematikk eller tilfeldighet? (Rapp. nr. 3). Oslo: Statens institutt for rusmiddelforskning SIRUS.

Fossum, B. (2003). Communication in the Health Service: Two examples. Stockholm: Karolinska Institutet. Division of Social Medicine.

Foucault, Michel m.fl. (2007). Security, teeritory, population: lectures at the Collège de France, 1977-78. Basingstoke: Palgrave Macmillan.

Freire, P. (1999). De undertryktes pedagogikk (2. utg.). Oslo: Gyldendal Akademisk.

Friestad, C. \& Hansen, I.L.S. (2004). Levekår blant innsatte. (Rapp. nr. 429). Oslo: FAFO.

Getz, L., Kirkengen, A.L., Ulvestad, E. (2011). Menneskets biologi - mettet med erfaring. Tidsskrift for Norsk legeforening (131)7, (s. 683-687).

Goffmann, E. (1975). Stigma: Om afvigerens sociale identitet. København: Gyldendal.

Graunbøl, H.M., Kielstrup, B., Muiluvuori, M.-L., Tyni, S., Baldursson, E.S., Guðmundsdóttir, H., Kristoffersen, R., Krantz, L. \& Lindstén, K. Retur: En nordisk undersøgelse af recidiv blant klienter $i$ kriminalforsorgen. Oslo: Kriminalomsorgens utdanningssenter KRUS.

Guy, R. (2011). Applied Sociology and Prisoner Reentry a Primer for More Successful Reintegration. Journal of Applied Social Science, (5)40. Doi:10.1177/193672441100500204.

Hansen, I.L.S. (2007): Møte med en likemann. Evaluering av WayBack-stiftelsen livet etter soning. Oslo: Fafo-notat 2007:03.

Hirschi, T. (1969). Causes of delinquency. Berkeley, CA: University of California Press. 
Hjemdal, O.K., Nilsen, S., Seim, S. (1997). Selvhjelp blant marginale grupper: - alternative strategier. (Rapp. nr. 1). Oslo: Høgskolen i Oslo.

Honneth, A. (2007). Kamp om anerkjennelse: Om de sosiale konfliktenes moralske grammatikk. Oslo: Pax Forlag.

Jackson, S.W. (2001). The Wounded healer. Bulletin of the history of medicine. (75)1, (s.1-36). Baltimore: Johns Hopkins University Press.

Langeland, E. (2014). Salutogenese og psykiske helseproblemer: en kunnskapsoppsummering. (Rapp. nr. 1). Trondheim: Nasjonalt kompetansesenter for psykisk helsearbeid NAPHA.

Larsson, J., Lauritzen, G. \& Ravndal, E. (2012). Gjennom 10 år: En oppfølgningsstudie av narkotikabrukere i behandling. (Rapp. nr. 6). Oslo: SIRUS.

Lebel, T.P. (2007). An Examination of the Impact of Formerly Incarcerated Persons Helping others. Journal and Offender Rehabilitation, (46)1-2, (s. 1-24). doi:10.1080/1050909670802071485.

Lemert, E.M. (1951). Is there a natural history of social problems? American sociological review, (16)2, (s. 217-223). Washington, D. C: The Association.

Lewis, Helen B. (1971). Shame and guilt in neurosis. New York: International universities, Inc.

Løgstrup, K.E. (1999). Den etiske fordring. Cappelens Forlag as.

Malterud, K. (2013). Kvalitative metoder i medisinsk forskning: En innføring (3. utg.). Oslo: Universitetsforlaget.

Mæland, J.G. (2012). Forebyggende helsearbeid: Folkehelsearbeid i teori og praksis (3. utg.) Oslo: Universitetsforlaget.

Revold, M.K. (2015) Levekårsundersøkelse blant innsatte 2014. Dokumentasjonsnotat 20015/38. Oslo: Statistisk sentralbyrå.

Riksrevisjonen (2014). Dokument 1 (2014-2015) for Justis- og politidep. Oslo. Hentet fra: www.riksrevisjonen.no/rapporter/documents/2014-2015/Dokument1/JD.pdf.

Rønning, R. (2007). Brukermedvirkning og empowerment - gammel vin på nye flasker? I O.P. Askheim \& B. Starrin (Red.), Empowerment i teori og praksis (s. 34-46). Oslo: Gyldendal akademisk.

Scheff, T.J. (2003). Shame in Self and Society. Symbolic Interaction, 26(2), (s. 238-262). Published by: Wiley on behalf of the Society for the study of Symbolic Interaction. URL: http://www.jstor.org/stable/10.1525/si.2003.26.2.239

Skårderud, F. (2001). Tapte ansikter. I T. Wyller (Red.), Skam: Perspektiver på skam, are og skamløshet $i$ det moderne (s. 37-52). Bergen: Fagbokforlaget.

Starrin, B. (2007). Empowerment som livsinnstilling - kan vi lære noe av Pippi Langstrømpe? I O P. Askheim \& B. Starrin (Red.), Empowerment i teori og praksis (s. 59-71). Oslo: Gyldendal akademisk.

Statistisk sentralbyrå SSB (2014). Fengslinger, 2012. Hentet fra: http://www.ssb.no/fengsling

Svennevig, G. (2012). WayBack: Det er aldri for tidlig å angre. Oslo: Z forlag.

Tveiten, S. (2007). Den vet best hvor skoen trykker ...: Om veiledning i empowermentprosessen. Bergen: Fagbokforlaget.

Vetlesen, A.J. (2009). Frihetens forvandling: essays og artikler 2002-2008. Oslo: Universitetsforlaget.

Weston, C.M. (2010). Fra skam til selvrespekt. Dansk Psykologisk Forlag. 